\title{
REVIEW \\ Petroleum Filling Stations and Their Impact on the Environment in Nigeria
}

\section{Ruth Oghenerukevwe Eyankware Ulakpa ${ }^{{ }^{*}}$ Wisdom Chukwuemeke Ulakpa $^{2}$ Oghenegare Emmanuel Eyankware ${ }^{3}$}

1. Department of Environmental Management and Pollution Control, Nigeria Maritime University, Okerenkoko, Nigeria

2. Federal University of Technology, Minna Niger State, Nigeria

3. University of Port-Harcourt Rivers State, Nigeria

\section{ARTICLE INFO}

Article history

Received: 9 November 2021

Accepted: 16 December 2021

Published Online: 22 February 2022

\section{Keywords:}

Petroleum filling stations (PFSs)

Environment

Health

Impact

Department of Petroleum Resource (DPR)

\begin{abstract}
The poor state of the environment, especially in urban areas, has become a major global issue, with developing countries such as Nigeria voicing growing concern. There is a scarcity of knowledge on the environmental impact of PFSs as a result of the loss of life and property, as well as other serious socio-economic implications of non-compliance with PFSs siting criteria. The historical literature on the impact of residential buildings, the environment, and human health on PFSs in Nigeria, as well as the study's gap, is examined in this research. It also outlines DPR compliance with PFSs location as well as established criteria for prohibiting PFS siting in Nigeria's states. Relevant publications on PFSs-related topics were downloaded from Google Scholar. The goal of this study is to look back on a previous essay about PFSs in Nigeria and its impacts on the environment and human health. This study's main purpose is to give a complete overview of Nigerian PFSs. According to the article analyzed, the majority of PFSs were located close to residents, with setbacks from the road and residential areas of less than $30 \mathrm{~m}$ in $90 \%$ of the filling stations. As a result, the landowners can band together to argue that a facility that is improperly sited cannot be built. A great deal of public participation is required. A campaign should be launched to raise awareness among filling station owners and other developers of the dangers of non-compliance with established norms. All violators of the established norms, as well as corrupt officials of enforcement agencies/bodies, should face open punishment so that others might learn their lessons. Finally, appropriate planning is required to allow future road expansion.
\end{abstract}

\footnotetext{
*Corresponding Author:

Ruth Oghenerukevwe Eyankware Ulakpa,

Department of Environmental Management and Pollution Control, Nigeria Maritime University, Okerenkoko, Nigeria;

Email: rutheyankware@yahoo.com
} 


\section{Introduction}

Volatile organic compounds (VOCs) are a diverse collection of substances distinguished by their relatively high vapor pressures. Exposure to these substances can cause asthma, headaches, mucosal symptoms ${ }^{[1]}$, and, in some situations (e.g., benzene), an elevated risk of cancer ${ }^{[2,3]}$. In Europe, benzene is the only VOC that is officially regulated in terms of air quality (Directives 2000/69/EC and 2008/50/EC). VOCs have indirect health consequences due to their role as ozone and other photochemical pollution precursors. PFSs are frequently the largest source of VOCs in metropolitan settings. Additional sources include traffic and small-scale companies that employ organic chemicals as solvents (paint, glue, etc.). Petrol stations as VOC emission sources have been the topic of much research in recent years, with a special focus on the design and evaluation of control systems in an effort to reduce environmental concerns and emissions ${ }^{[4,5]}$. Mostly those concerning their effects on employees and environmental issues ${ }^{[6-11]}$.

Several studies in the worldwide literature have looked at local projections of petroleum vapours on petrol station workers' health and the impact of petrol stations on their immediate surroundings, and gas stations as a major source of VOCs ${ }^{[12,13]}$. The inclusion of petrol stations within residential zones in human settlements was determined by the uncontrolled and rapid sprawl of built-up houses unique to Romanian urban ecosystems ${ }^{[14]}$. This is why we're interested in doing a temporal analysis of incompatible land use and land-cover to find evidence for the velocity of change in terms of locational conflicts between residential areas and gas stations. The high VOC pressure on air quality provided a legislative framework at the European level: Directive 1999/13/ EC which promotes the reduction of VOC emissions caused by the use of organic solvents in certain activities and installations; and Directive 94/63/EC, which highlights that VOC emissions contribute significantly to air pollution $^{[15,17] .}$

Although Spanish petrol stations were traditionally located in relatively empty areas, the country's continual urbanization has resulted in numerous petrol stations being established within metropolitan areas surrounded by structures in recent years. This issue has sparked a debate between residents whose homes are close to gas stations and the authorities in charge of land management. With oil products, the residential areas-gas stations relationship can cause fires, increased traffic, noise, pollutants, waste, and wastewater ${ }^{[16]}$. The climate zone, road network features, and urban agglomeration all amplify these effects ${ }^{[17]}$. The haphazard expansion of built surfaces in Romania, particularly residential areas, has resulted in the replacement of the terrain profile, from one productive to one consumer, as well as the residential areas' closeness to opposing functions ${ }^{[18]}$. In general, gas stations are positioned only for economic reasons, with little consistency in issuing building certificates and no proper oversight of conformity with territorial planning requirements. Environmental endowments are modest, and environmental components are only superficially monitored at these gas stations. All of them are linked to excessive VOC emissions (particularly benzene), which cause structural disequilibrium in environmental components.

In physical planning practices all throughout the world, the easy-going methods and littering of fuel filling stations in approved residential land uses are unsafe, pervasive, and forbidding. Even though anthropogenic actions such as petrol filling stations and related commercial land use development continue to fail the environmental impact evaluation test of acceptance, compatibility, suitability, and standard on a daily basis in developing countries around the world, are common in residential neighborhoods. In Sub-Saharan Africa, however, formal analysis of other land uses, such as fuel filling stations, in order to determine their social and environmental advantages and disadvantages in terms of layout or residential neighborhoods is no longer required. The reasons for this exceptional rise are not difficult to imagine. The oil business became a major source of energy with the start of the industrial revolution at the turn of the twentieth century, owing to the rise of the vehicle industry. Although oil is an important petrochemical feedstock, it is also a source of energy for the global economy ${ }^{[19]}$. As can be seen from the above data, oil has played a significant role in the growth of technology in our day. However, oil finding, like any other technique, has its drawbacks. One of these disadvantages is its harmful impact on the earth's biosphere, which includes the release of pollutants and greenhouse gases into the environment, as well as ecosystem damage from occurrences like oil spillage ${ }^{[20]}$. As a result of this predicament, developed countries are beginning to 
place a greater emphasis on a cleaner, more environmentally friendly energy source. Nigeria's energy needs are provided by petroleum and natural gas reserves, which are plentiful. The Nigerian economy is heavily reliant on crude oil exports. The recent population growth in Nigeria has prompted a rise in demand for petroleum goods, and many marketers have taken advantage of this need by arbitrarily constructing service stations without considering the potential impact of their locations ${ }^{[21]}$. The rapid growth of built-up gas filling stations in primarily residential neighborhoods in developing nations, including Nigeria, is concerning and poses issues for a sustainable environment as well as violations of land use arrangements and environmental aesthetics ${ }^{[22]}$. Opinions show the accumulating and obstinate glassiness of these phenomena in Nigerian residential zones, exacerbated by quick approval, poor evaluation, and control of such developmental projects in residential areas by the relevant agencies, which are safekeeping physical planning and urban development without regard for the attendant environmental and health implications.

The condition can also be a result of land use modification or conversion, such as the continued presence of escalating petrol stations in various types of residential areas. It causes problems since extremely flammable petroleum products are frequently stored in residential zones in constructed underground tanks for retail purposes. Furthermore, the inability of petrol station developers to comply with the necessary laws guiding the development of such activities, as well as a lack of strict control by appropriate agencies, contribute to the location of such commercial land use in the residential domain of Nigerian urban areas, as more filling stations are built in order to meet demand. As a result of the current scenario, it is becoming increasingly frequent to find fueling stations positioned close to residential areas. The consequence of this development is increased air pollution due to the ongoing release of hazardous chemicals into the atmosphere. These emissions come from a variety of sources, including gasoline delivery to stations, tank breathing caused by temperature and pressure fluctuations during vehicle refueling, emissions from loosely closed tanks, and leakage caused by mishandling of petroleum ${ }^{[21]}$. There is also the emission of combustion products from the station's vehicle engines ${ }^{[23]}$. PFSs, as retail outlets for highly flam- mable petroleum resources such as gas, gasoline, and kerosene, must be strategically situated in relation to other operations to minimize the damage on the nearby environment. Petrol stations along the route were found to be too close together; some were even built side by side, resulting in a greater likelihood of massive and wide-ranging consequences on the nearby environment. The positions of gas stations in relation to road crossings and U-Turns, as well as their setbacks from the expressway, a high-tension power line, and adjacent land uses, have generated concerns about the area's safety. Because power supply in Nigeria is known to be unreliable, many, if not all, of the stations are planned to use privately owned generating facilities, which may cause some noise and air pollution in the immediate environment. Another source of concern is the rowdiness at and near gas stations, especially when there is a shortage of fuel. Economic expansion is now widely acknowledged as a major contributor to developing environmental challenges, particularly when such development is not sustainable.

The following are the objectives of this article: to examine the effects of the expansion of PFSs in new locations on the environment and human health; examine EIA requirements for PFS site suitability; and examine the impact of their locations in order to find a long-term solution to the problems.

\section{Description of the Study Area}

Nigeria is located in the West African sub-region between longitudes 30 and $140 \mathrm{E}$ and latitudes 40 and $140 \mathrm{~N}$ as shown in Figure 1. It has a total area of 923,768 square kilometers. It is bordered to the North by the Republics of Niger and Chad, and to the West by the Republic of Benin. It shares Eastern borders with Cameroon all the way down to the Atlantic Ocean's coasts, establishing the Nigerian Territory's Southern boundaries.

Despite being totally inside the tropics, Nigeria's climate ranges from tropical on the coast to sub-tropical in the interior. The wet season runs from April to October, with the dry season being from November to March. The extreme maximum temperature in Southern coastal locations can reach $370{ }^{\circ} \mathrm{C}$, while the extreme low is $100^{\circ} \mathrm{C}$. Temperature extremes can vary from 400 to 5000 degrees Celsius further north, and the climate is drier ${ }^{[24]}$ 


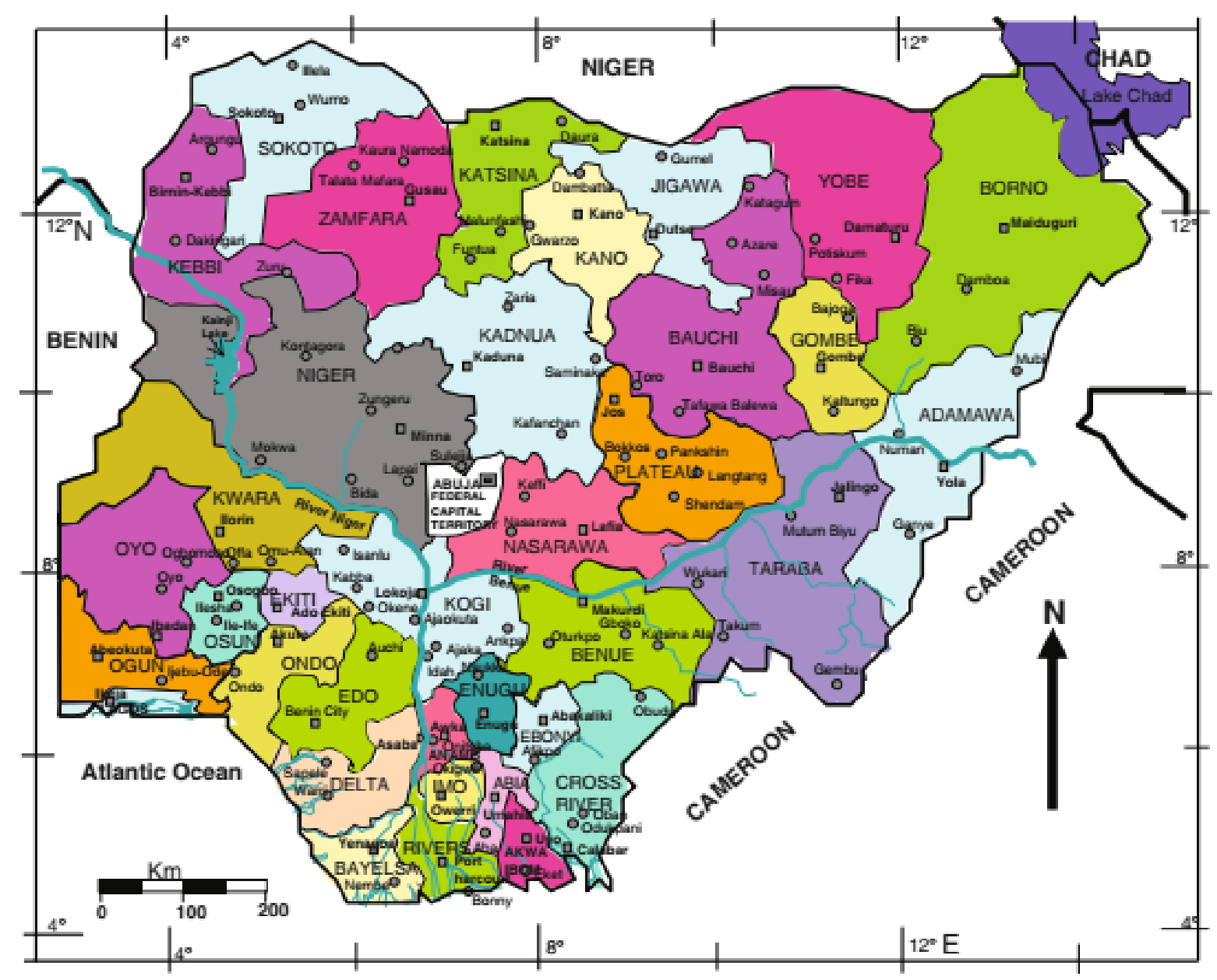

Figure 1. Nigerian map depicting the federating states ${ }^{[24]}$.

\section{Methods}

In Nigeria, a similar technique was used to review PFSs, and the same was used in order to assess the environmental impact of petrol pumping stations near residential areas in Nigeria, as well as to suggest mitigating techniques, articles from the last 5-10 years were examined ${ }^{[25]}$. Articles relevant to this study were found using Google search engines and open access journal sites. These articles and papers were reviewed in their entirety, and the data was entered into a database containing the authors' names, publication details, study site, time period, strategy, and technique for studying the impact of filling stations on man and the environment, as well as the major conclusion.

Furthermore, multiple methods were employed for this study with some modifications to satisfy the goal and objectives of this paper, which was to interpret the status and quality of work done within and outside Nigeria. The following approaches were used to evaluate the quality of the articles; the environmental and human health consequences of the proliferation of PFSs in previously uncharted territory; to research EIA standards for PFS site selection suitability, and to assess the impact of their sites in order to provide a long-term solution to the difficulties.

\section{Results and Discussion}

\subsection{Impacts of the Proliferation of PFSs with Their Unprecedented Locations It Has on the Environment}

Several researches have demonstrated the problems associated with the environmental impact of PFSs in Nigeria. The manner in which petrol fuel outlets are sandwiched in residential zones of Nigerian urban centers without regard for the health and environmental consequences is not encouraging. An empirical study was conducted on contaminants released from PFSs and their impact on air quality ${ }^{[26]}$. Their findings revealed that the main contaminants identified in the environment air were volatile organic compounds, methane, and carbon monoxide, with impurity levels exceeding the FEPA air quality limit. Over 98 percent of PFSs met the minimum 
reserve of 100 meters from health care centers and various gas stations in order to achieve the 400-meter basic station distance guideline ${ }^{[27]}$. PFSs have been found to be abundant near roadways and residential buildings in previous research. Similar research has demonstrated that the locational pattern of nearby petrol filling stations has a propensity to cluster in a specific zone. The study recommends that petrol stations be closed or restricted in and around the town's built road flight path and strictly designated residential zones ${ }^{[28]}$.

The buffer analysis and descriptive statistics to evaluate the proximity of PFSs to residential buildings in the Bucharest suburbs discovered that the presence of PFSs has resulted in malfunctions, highlighting a disadvantage area due to environmental issues, unplanned development, overburdened infrastructure, and pollution of each environment component ${ }^{[29,30]}$. They evaluated the survival of filling stations and urban infrastructure to qualify check maintenance on compliance. In their research, they discovered that while $50 \%$ of gas stations followed the rules, the remaining $50 \%$ did not. According to the researchers, preparedness should be based on the adequacy, functionality, and sophistication of available extinguishing facilities. Setback standards and safety preparedness policies should be improved for long-term urban development ${ }^{[31]}$. The study on the locational distribution of petrol stations and the underlying ramifications in Osun City, Nigeria's commercial density shows that about $56 \%$ of PFSs followed the area coverage standards, implying that the petrol stations' clustering was endangering the area's safety ${ }^{[32]}$.
Land-use activities along arterial highways in several Nigerian cities are not regulated or coordinated, exposing the region to threats such as traffic bottlenecks, pollution, accidents, fire explosions, and other environmental issues. These filling stations serve as a major contributor to traffic problems such traffic congestion, pollution, fire, and explosion in densely populated regions ${ }^{[33]}$. According to him, the degree of these varies depending on factors such as location, size, and distance from the road, among others. It is believed that the air quality near fuel stations and their environs (which is mostly influenced by vapor emissions from unburned gasoline) differs from the ratio seen in city air, which is primarily influenced by traffic emissions ${ }^{[21]}$. Petroleum distribution is a complicated task that entails carrying and storing across the country ${ }^{[34]}$. The location of filling stations and their impact on the environment in different parts of Nigeria was investigated ${ }^{[33,35,36]}$. In Kaduna North the spatial distribution of filling stations was analyzed, from the result it was discovered that the 22 PFSs in the area are irregularly dispersed and largely clustered along key highways ${ }^{[33]}$. The analysis did not consider the impact of the spatial distribution of these filling stations on traffic flow along the highway which contradicts ${ }^{[35]}$. According to research conducted in Spain, gas stations contribute significantly to ambient benzene concentrations in their vicinity as a result of the non-conformity of filling station locations to statutory criteria on traffic flow ${ }^{[37]}$. Table 1 shows the results.

In Romania the haphazard growth of PFSs and their closeness to residential buildings, made residents in Ro-

Table 1. A Brief Comparison of the Distance Between PFSs in Nigeria

\begin{tabular}{|c|c|c|c|c|c|}
\hline From & To & Location & Kilometer & Meter & References \\
\hline NNPC Mega Conoil & Federal road & Abuja- Keffi road & 0.05 & 50 & [21] \\
\hline Oando & Residential Buildings & Isoko road Ughelli & 0.05 & 50 & Field Study, 2021 \\
\hline Conoil & Businesses centers & Kubuwa Abuja & 0.1 & 100 & Field Study, 2021 \\
\hline Century & New path & Okpanam road Asaba & 0.3 & 300 & Field Study, 2021 \\
\hline Texaco & Total & Abuja-Keffi road & 0.1 & 100 & [21] \\
\hline Total & Mobil & Isoko road Ughelli & 0.2 & 200 & Field Study, 2021 \\
\hline Rain oil & Federal road & Asaba-Agbor road & 0.1 & 100 & Field Study, 2021 \\
\hline Conoil & Residential Buildings & Rumuokuta -Mgbuoba road & 0.2 & 200 & Field Study, 2021 \\
\hline Total & State road & Agbani-Enugu road & 0.3 & 300 & Field Study \\
\hline NNPC mega stations & State road & Douglas road Owerri & 0.05 & 50 & Field Study \\
\hline AA Rano Nig. Ltd. & Federal road & Mararaba & 0.1 & 100 & Field Study \\
\hline Mobil & State road & Kurunduma & 0.5 & 500 & Field Study \\
\hline Oando & State road & Kuchikau & 0.14 & 140 & Field Study \\
\hline Total & State road & Masaka & 0.14 & 140 & Field Study \\
\hline NNPC & Federal road & Ado & 0.75 & 750 & Field Study \\
\hline
\end{tabular}


mania to believe that the affiliation of home gasoline stations can cause fires, increased traffic, noise, pollution, trash, and wastewater by using oil products ${ }^{[18,17]}$. This is consistent with the findings of the location and spatial distribution of PFSs in Ilaro, Ogun State ${ }^{[38]}$. The study of PFSs in Ilesa, Osun State, Nigeria concludes that numerous filling stations were haphazardly spread along with it, with some more under construction, and that filling stations along the road were discovered to be too close to each other; some were even developed side-by-side, implying a higher propensity for massive and wider effects on the immediate environment ${ }^{[39]}$. A variety of factors impact the location of a petrol station in the Accra district $^{[40]}$. The study's findings revealed that factors such as promotion, brand, pump pricing, service quality, opening hours, local authority assessment, and location size influenced siting. As a consequence of the study's findings, a fuel station placed in a high-traffic region, a struggle along the road, the area's land use activities, and the road's condition, including environmental and regulatory requirements, are all desirable. In the Nigerian city of Port Harcourt, there is an agreement that the spatial attribute for locational analysis of petroleum stations is that filling stations have been converted to residential houses, and 14 filling/ petrol dispensable engines are located near the road, and one is located near a high tension line ${ }^{[17,40]}$.

Researches on the impact of PFSs on petrol stations in Kampala, Uganda were compared to studies on the level of compliance of PFSs with development control requirements in Anambra, Nigeria ${ }^{[41,42]}$. As the distances between the filling stations sampled from the road and the setback standards are significantly different, the results of their study suggested that the aforementioned explain why houses located 100 meters from stations were prone to sensible height and those 50 meters' analyses were rated the peak of the risk, as the distances between the filling stations sampled from the road and the setback standards are significantly different. Further studies revealed that the environmental problems of developed fuel filling stations in the residential domain are also numerous, including volatile organic compounds, methane, and carbon monoxide, to name a few in Port Harcourt Rivers State ${ }^{[22]}$.

The increase in the global population has outpaced, and automobiles, including Premium Motor Spirit (PMS), have posed a serious threat to human health in terms of providing the Liquified Natural Oil, Kerosene, Dual Purpose Kerosene masses with the necessary infrastructure, enact, and (DPK), Aviation Turbine Kerosene are sold ${ }^{[43]}$. As the population of completed white petroleum products grows, so does the number of automobiles that run on flammable vapour at very low temperatures.

The fact that certain hydrocarbons found in PFSs are effective inducers of cytochrome P450 was demonstrated in the introduction section of the research, which could lead to biological and physiological effects. Following car refueling, a significant level of benzene was observed in the pulmonary zone of PFSs ${ }^{[44]}$. Benzene and similar hydrocarbons produced by PFSs are metabolized by a highly reactive intermediate epoxide that binds to hepatic microsomal proteins and nucleic acids, causing lethal consequences in humans ${ }^{[45]}$. Because petroleum hydrocarbons and other related carbon-containing compounds, particularly mammalian liver and kidney cells, are converted into free radicals or activated metabolites during oxidation in cells it was deemed necessary to assess the extent of PFSs' impact on human health and, if possible, quantify it ${ }^{[45]}$. Unlike decades earlier, when PFSs were sporadically spread, most of the activities of PFSs were connected to contemporary day development in some way.

It is believed that PFSs hydrocarbons activated metabolites, when reacted with some cellular components, such as membrane lipids, to form lipid peroxidation products, could contribute to membrane alteration ${ }^{[46]}$. They went on to say that this could react with enzymes and cause inactivation by oxidizing proteins and/or breaking DNA strands. Because their metabolites can attach to proteins and nucleic acids, they can trigger these latter effects. Studies also shown that PFS exposure has resulted in significant alterations in the activity of numerous enzymes in China particularly in the tissues of the liver, kidneys, and lungs ${ }^{[47,48]}$. The potential health risks of Owerri's petrol station personnel were assessed ${ }^{[49]}$. The results show a significant increase in alkaline phosphatase, analine, and aspartate amino transfer activities in people exposed to petrol vapour for 6-10 years. Individuals exposed to petrol vapour had significant amounts of serum urea, creatinine, and urine protein, according to the findings.

Qualitative interviews were conducted to confirm the discovered parameters of PFSs in Ife-Central using an inductive manner. The findings show that all of the PFSs violate the principles and criteria because the distribution was clumped, negatively impacting the residents' well-being, the environment, and their socioeconomic situation ${ }^{[50]}$. PFSs siting has resulted in the release of volatile organic compounds such as benzene and toluene, as well as toxic gases such as carbon monoxide and traces of soot, all of which have been shown to have a negative impact on general health and environmental hazards ${ }^{[51]}$. Table 1 shows the results. 
Table 2. Benzene concentrations $\left(\mu \mathrm{g} \cdot \mathrm{m}^{-3}\right)$ measured by personal (R) or by fixed site monitors $(\mathrm{S})$ placed in or around of petrol station.

\begin{tabular}{|c|c|c|c|c|}
\hline Local & Period & Observations (n) & Study Type (Sx) & References \\
\hline United States & $1981-83$ & 72 & Rnc & [52] \\
\hline Europe & 1986-1992 & & Rnc & [53] \\
\hline United Kingdom & 1995 & - & $\begin{array}{l}\text { Rnc } \\
\text { Rc }\end{array}$ & [54] \\
\hline Valencia (Spain) & - & 7 & $\mathrm{R}$ & [55] \\
\hline Kolkata (India) & $2005-2006$ & 35 & $\mathrm{R}$ & [56] \\
\hline $\begin{array}{c}\text { Ioannina (Greece): } \\
\text { - urban } \\
\text { - rural }\end{array}$ & 2006 & $\begin{array}{l}30 \\
30\end{array}$ & $\mathrm{Rc}$ & [57] \\
\hline $\begin{array}{c}\text { Ioannina (Greece) } \\
\text { - urban } \\
\text { - rural }\end{array}$ & 2006 & $\begin{array}{l}32 \\
32\end{array}$ & $\begin{array}{c}\mathrm{Rc} \\
\mathrm{R}\end{array}$ & [58] \\
\hline Owerri (Nigeria) & $2005-2007$ & 40 & Rnc & [59] \\
\hline Italy & - & 28 & $\mathrm{R}$ & [60] \\
\hline Kano (Nigeria) & 2008 & 214 & Rnc & [38] \\
\hline Illorin (Nigeria) & 2018 & 297 & $\mathrm{Rc}$ & [61] \\
\hline Anambra (Nigeria) & 2019-2020 & 270 & Rnc & [42] \\
\hline Ife- central (Nigeria) & 2021 & 52 & Rnc & [50] \\
\hline Ede Osun state (Nigeria) & 2021 & 14 & Rnc & [62] \\
\hline
\end{tabular}

-: the requested information was not found; Rnc: refueling without an installed emission control system; Rc: refueling with an installed emission control system; R: refueling without knowing whether or not an emission control system is in place; Sx: a study conducted at a maximum distance of $\mathrm{x}$ meters around a petrol station.

\subsection{EIA Requirements for Suitability of Site Selection of PFSs}

Construction activities are anticipated to cause severe environmental harm, which is a major worry. Rail projects, fuel pumping stations, and infrastructural facilities all have the potential to impact the environment, including soil degradation, air pollution, and water contamination ${ }^{[50,63-66]}$. The main challenge for developers today is to establish and implement a strategy for sustainable building operations that is both environmentally friendly and longterm ${ }^{[67-69]}$. Continuous urbanization creates a fair demand for automobiles, resulting in increased fuel consumption and filling station demand ${ }^{[70]}$. In a same line, the bulk of PFSs in Ede Osun state did not adhere to planning criteria. Implementing a public awareness campaign among residents and enforcing planning standards in existing PFSs and other land uses will go a long way toward addressing the issues of low perception and non compliance with planning standards. Filling stations and electric charging stations for future cars meet the increased demand for fuel. The PFSs have a significant potential to harm the site and the surrounding environment, according to reports. It also has an effect on socioeconomic losses, environmental deterioration, geological disintegration, and water contamination ${ }^{[71-73]}$. One of the most serious hazards of PFSs is fire, which is compounded by other factors such as electricity ${ }^{[70]}$ and pipe and underground storage tank leakage, which can lead to groundwater contamination ${ }^{[74]}$. Furthermore, it causes air pollution from aromatic compound concentrations ${ }^{[75]}$ as well as traffic congestion ${ }^{[70]}$. The PFSs facility is necessary, but it is also dangerous. As a result, particular care must be used when selecting such a facility. Any company project's site selection is crucial ${ }^{[76,77]}$. Several incidences involving fires at gas stations and filling stations have already been reported in the news, with fatalities. It has a variety of effects on the industry as well as the mental health of users. Take a look at Figure 2.

\section{Perceptions of Residents on Danger Associated with Petrol Stations in Nigeria}

Researchers continue to be interested in developing a sustainable way to maintain the natural environment. Construction field activities that can harm the environment have long been a source of worry. The structure of such places has the potential to cause significant environmental damage. A PFSs improves transporter and traveler convenience, but these stations are frequently dangerous ${ }^{[74,78]}$. Site selection is frequently cited as an important factor 


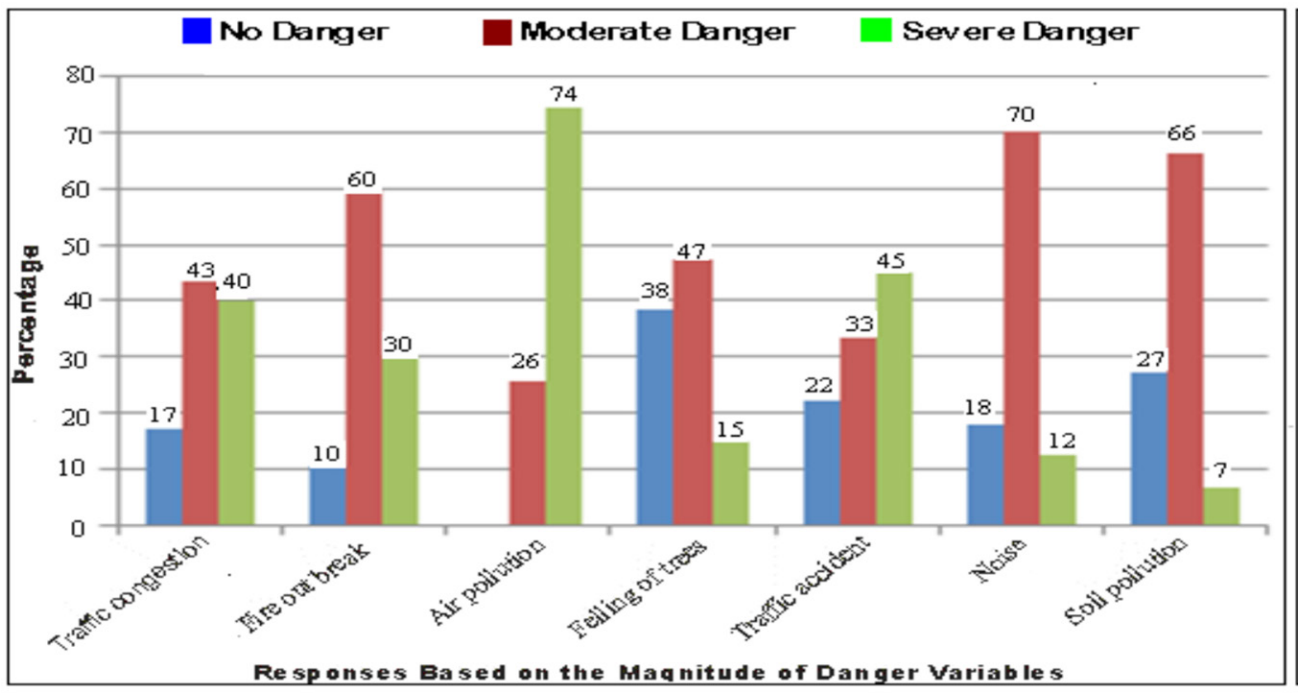

Figure 2. Perceptions of Residents on Danger of the Presence PFSs ${ }^{[35]}$.

in the success of any business venture. This industry has become increasingly concerned about major environmental issues and negative consequences around the world. Petroleum retail companies are attempting to implement sound and effective environmental policies for PFSs. The EIA was created as an effective instrument for better management of such assets for this aim. Using regression and GIS, the PFS's position is determined by traffic volume counts ${ }^{[79]}$.

The amount of clients who visit per day determines the site's potentiality, which is critical for business growth. A study was carried out in the Kano Metropolitan Area in Northern Nigeria to ascertain the concern of businesses in the sector of petrol retailing for taking physical planning requirements into consideration ${ }^{[80]}$. The requirements stated for planned construction were found to be ignored by eight (8) stations (4\%) out of 192 stations ${ }^{[78]}$. As illustrated in figure $3 \mathrm{a}$ and $3 \mathrm{~b}$. It is said that building crews for petrol-filling stations prefer to choose a site based on personal preferences; however, for environmental protection and other preventive measures, a uniform method is required. Furthermore, it is noted that an EIA study is required prior to obtaining approval for the fuel site ${ }^{[81-84]}$.

EIA entails the necessary examinations and analyses of a project's environmental viability. The methods and procedures involved in completing EIA reports take a significant amount of time, effort, and money ${ }^{[85,86]}$. The older approaches of site selection incorporate both qualitative and quantitative elements when deciding on a place. Because various factors are still involved in the EIA analysis of any facility, such as an FS, these studies lack factors considered in EIA assessment. And FS is a significant environmental liability since it poses a risk to the environment's well-being. As a result, a site study and general risk assessment are required before such facilities may be built $^{[87]}$.
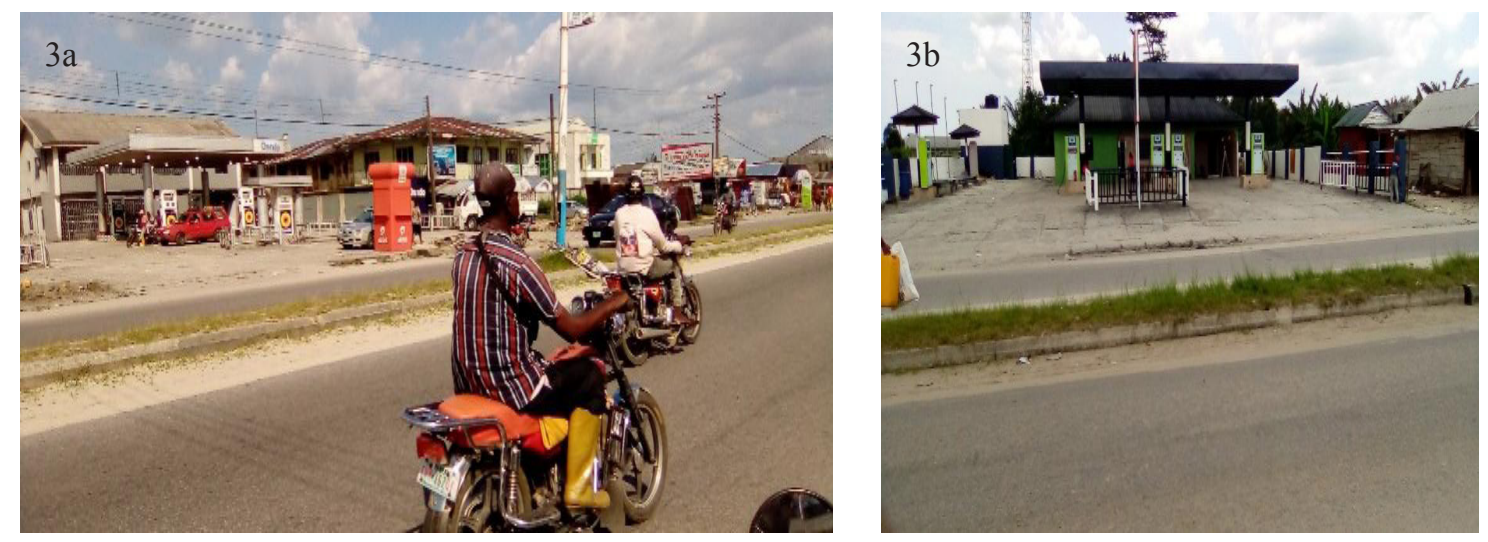

Figure 3a and 3b. Displaying PFSs with no setback to residential buildings in Delta and Imo State.

Source: Researchers' Fieldwork, 2021. 
The level of awareness of risks and safety precautions among PFSs, as well as the existing safety practices in Petrol Filling Stations in Minna, Niger State, Nigeria was investigated. According to the statistics, $45 \%$ of PFSs in Minna do not meet Department of Petroleum Resources (DPR) siting requirements, with setbacks from the road and residential areas of less than 30 meters ${ }^{[88]}$. Independent Petroleum Marketers are unconcerned about people selling gallon-sized petroleum products in front of their stations. When opposed to those run by individual marketers, conglomerate-owned stations, such as the Nigeria National Petroleum Cooperation (NNPC) Retail Outlets(State owned), have stronger safety procedures and orientations.

GIS was used to conduct a location analysis of PFSs in Ilorin, Kwara State, Nigeria. The coordinates of the stations were recorded using a handheld Global Positioning System (GPS) device, and other data were gathered by presenting questionnaires to the owners and workers in each PFSs. During their investigation, they determined that the majority of the stations were near buildings, with $10(3 \%)$ being near a school, $226(76 \%)$ near retailers, 192 (65\%) near residential houses, and 11 (4\%) being near hospitals ${ }^{[61]}$. The study reveals that PFSs are overly packed throughout the metropolis, resulting in cluster patterns that pose a major hazard to the town's heavily populated districts and are not constructed in compliance with existing norms. In Malaysia, a similar study was carried out to determine suitable land parcels for the installation of new PFSs ${ }^{[89]}$. According to them, the Ipoh Mapping and Surveying Department provided the geographic data, while the Ipoh City Planning Department provided the norms used in practice for site selection for PFSs. They prepared a questionnaire to get feedback on the PFSs location choices from stakeholders. During their investigation, they revealed that the vast majority of PFSs failed to meet the specified guidelines for position and distance from residential residences, which served as the foundation for future PFSs construction as shown in Figure $4 \mathrm{a}$ and $4 \mathrm{~b}$.

\section{Conclusion}

As a result of the foregoing, it is clear that PFSs are forming in Nigeria without consideration for existing physical planning norms, putting the environment, as well as human and public health, in jeopardy. The majority of inhabitants, unfortunately, were unaware of the health risks associated with the petrol stations' infractions of planning requirements. As a result, the DPR must ensure that planning standards are properly enforced in Nigeria in order to protect public health and encourage healthy urban expansion. The relevant authorities also demand that fuel stations, as well as any other physical developments, be installed throughout the country, as well as public awareness campaigns about the environmental and health risks involved with such developments. These kind of campaigns can be carried out with the help of the media and collaboration with traditional rulers and local groups.

\section{Recommendation}

In light of the study's findings, the following recommendation was made:

i. The law should empower the planning officer (s) to
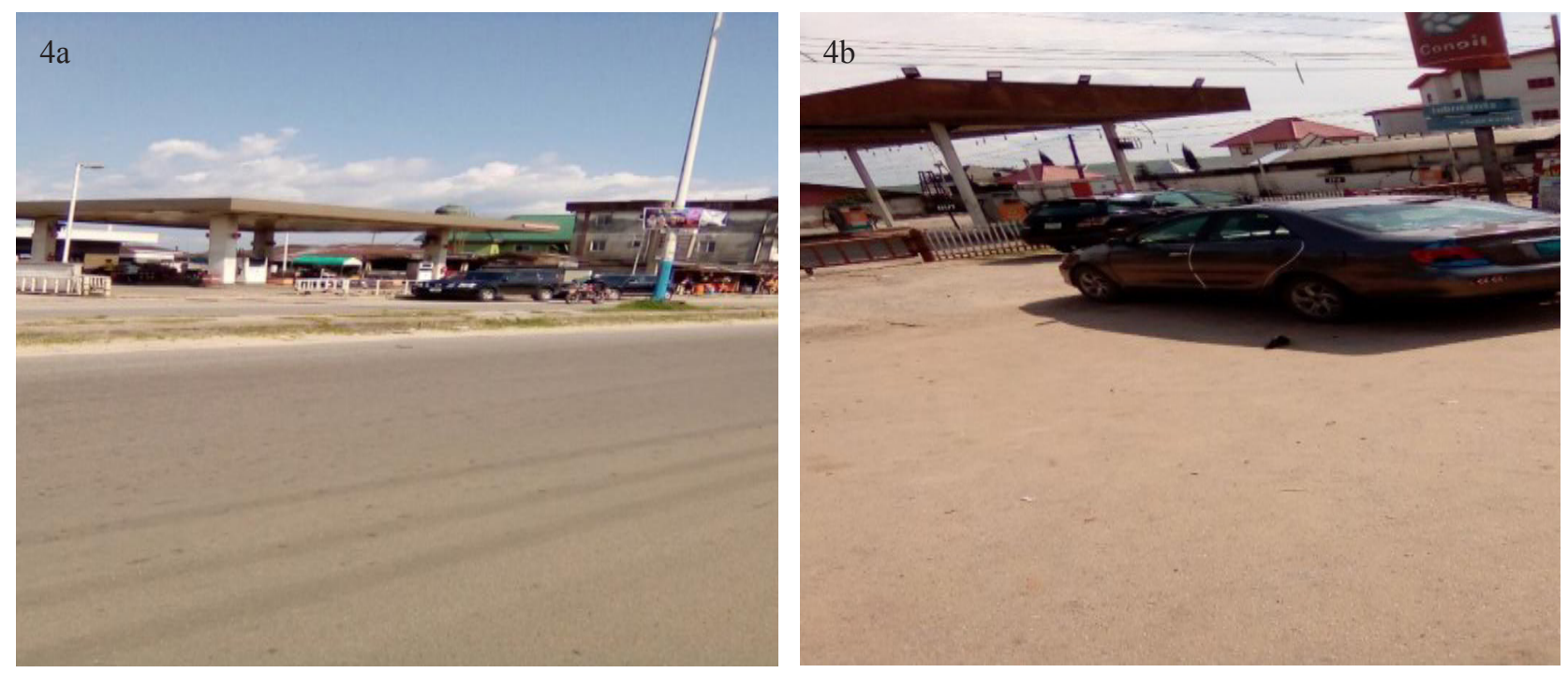

Figure 4a and 4b. Showing PFSs close to Residential Buildings in FCT and Rivers State 
investigate all instances of illegal development, as well as plans submitted by non-planners without the planner's permission.

ii. Public participation is important because landowners can band together and say that a facility that is poorly located cannot be built.

iii. A campaign should be initiated to increase awareness among filling station owners and other developers of the dangers of non-compliance with set requirements.

iv. All violators of the established criteria should face open punishment in order for others to learn from their mistakes.

\section{Conflict of Interest}

The authors declare no conflict of interest.

\section{References}

[1] Steinemann, A.C., 2008. .Fragranced consumer products and undisclosed ingredients. Environmental Impact Assessment Review. 29, 32e38.

[2] Ott, M.G., Townsend, J.C., Fishbeck, W.A., et al., 1978. Mortality among workers occupationally exposed to benzene. Archives of Environmental Health. $33,3 \mathrm{e} 10$.

[3] Lynge, E., Andersen, A., Nilsson, R., et al., 1997. Risk of cancer and exposure to gasoline vapors. American. Journal of Epidemiology. 145, 449e458.

[4] Uren, S.A., 1997. Pilot study to assess benzene concentrations in the vicinity of petrol stations. Croydon. Available on the Internet. UK Department of Environment, UK. http://www.environmental-center.com.

[5] Ohlrogge, K., Wind, J., Hassel, D., 2000. New technology for emission reduction at petrol stations". In: Czech Association of IUAPPA (International Union of Air Pollution Prevention and Environmental Associations) (Ed.). Conference Proceedings of the 12th Regional Central European Conference IUAPPA and 4th International Conference on Environmental Impact Assessment. pp. 418e425.

[6] Brugnone, F., Perbellini, L., Romeo, L., et al., 1997. Environmental exposure and blood levels of benzene in gas station attendants.Comparison with the general population. Medicinadel Lavoro. 88, 131e147.

[7] Periago, J.F., Prado, C., 2005. Evolution of occupational exposure to environmental levels of aromatic hydrocarbons in service stations. Annals of Occupational Hygiene. 49, 233e240.

[8] Gonzalez-Flesca, N., Vardoulakis, S., Cicolella, A., 2003. BTX concentrations near a stage II implemented petrol station. Environmental Science and Pollu- tion Research 9, 169e174.INSHT'.National Institute of Safety and Hygiene at Work.Ministry of Labor and Immigration, Government of Spain.http://www.insht.es/ portal/site Insht/menuitem.a82abc159115c8090128ca$10060961 \mathrm{ca} /$ ?vgnextoid $1 / 44458908 \mathrm{~b} 51593110 \mathrm{VgnVC}$ M100000dc0ca8c0RCRD.

[9] Palmgren, F., Hansen, A.B., Berkowicz, R., et al., 2001. Benzene emission from the actual car fleet in relation to petrol composition in Denmark. Atmospheric Environment. 1, S35eS42.

[10] Srivastava, A., Joseph, A.E., More, A., et al., 2005. Emissions of VOCs at urban petrol retail distribution centers in India (Delhi and Mumbai). Environmental Monitoring and Assessment. 109, 227e242.

[11] Fernández-Villarrenaga, V., López-Mahía, P., Muniategui-Lorenzo, S., et al., 2005. Possible influence of a gas station on volatile organic compounds levels in the ambient air of an urban area. Fresenius Environmental Bulletin. 14, 368e 372.

[12] Periago, J.F., Prado, C., 2005. Evolution of occupational exposure to environmental levels of aromatic hydrocarbons in service stations. Ann. occup.Hyg. 49(3), 233-240.

[13] Terrés, M., Minarro, D., Ferradas, G., et al., 2010. Assessing the impact of petrol stations on their immediate surroundings. Journal of Environmental Management. 91, 2754-2762.

[14] Patroescu, M., Nita, M.R., Ioja, I.C., et al., 2009. New residential areas in Bucharest metropolitan area location, type and characteristics. Real Corp Proceedings. pp. 767-772.

[15] 18 Directive 94/63/EC on the control of VOC emissions resulting from storage of petrol and its distribution from terminal to service stations, Available. http://eur-lex.europa.eu/LexUriServ/LexUriServ. do?uri=OJ:L:1994:365:0024:0033:EN:PDF, accessed at 18.XI.2011

[16] Ioja, I.C., Onose, D., Cucu, A., et al., 2010. Changes in water quality in the lakes along Colentina River under the influence of the residential areas in Bucharest. Selected Topics in Energy. Environment, Sustainable Development and Landscaping. pp. 164-169.

[17] DeRoos, A., Davis, S., Colt, S., et al., 2010. Residential proximity to industrial facilities and risk of non-Hodgkinlymphoma. Environmental Research. 110, 70-78.

[18] Ioja, I.C., 2008. Methods for evaluating the quality of the environment in the metropolitan area of Bucharest. Bucharest: University of Bucharest Publishing House.

[19] Joseph, P., Riva, J.R., 2010. The history of the words 
petroleum industry. Newyork publisher. 1, 6-7.

[20] Timothy, P.M., 2006. Health and environment effect of air pollution. USEPA publications. pp. 23-25.

[21] Isabel, M.C., Graciela, A., Monica, R.C., 2010. Evaluating emission from gas stations. Journal of environmental management. 6, 42-50.

[22] Amakiri-whyte, B.H., Aselemi, A.E., Akpabio, M.U.A., 2021. Causes and Environmental Problems of Petrol Filling Stations in Residential Domain of Nigeria Town. International Journal of Research and Scientific Innovation. 8(1), 2321-2705.

[23] Ulakpa, R.O.E., Ulakpa, W.C., 2021. A Review on the Effects of Fumes from Tricycles (Keke) on Health and Environment, Nigeria. An International Scientific Journal. 40, 49-64.

[24] Nuhu, G.O., 2019. Geology and Mineral Resources of Nigeria.

DOI: https://doi.org/10.1007/978-3-540-92685-6.

[25] Eyankware, M.O., Igwe, E.O., Ulakpa, R.O.E., 2020. Achieving Sustainable use and Management of Water Resources for Irrigation in Nigeria. Review. Journal of Environment and Earth Sciences. 2(2), 47-55.

[26] Okonkwo, U.C., Orji, I.N., Onwuamaeze, I., 2014. Environmental Impact Assessment of Petrol and Gas Filling Stations on Air Quality in Umuahia, Nigeria. 13(1), 12-20.

[27] Mohammed, M.U., Musa, I.J., Jeb, M.U., 2014. GISBased Analysis of the Location of Filling Stations in Metropolitan Kano against the Physical Planning Standards. American Journal of Engineering Research (AJER). pp. 147-158.

[28] Olapeju, O., 2017. Assessing The Location and Spatial Distribution of Petrol Filling Stations in Ilaro, Ogun State. National environmental conference of the school of environmental studies. pp. 1-13.

[29] Cristian I.I., Constantina, A.T., 2012. Temporal analysis of incompatible land-use and land-cover: The proximity between residential areas and gas stations in Bucharest suburban area. Elsevier, Procedia Environmental Sciences. (14), 49 - 58.

[30] Sulaiman, Y., 2019. Analysis of Locational Compliance and Fire Safety Preparedness among Petrol Filling Stations in Dutse Town, Jigawa State. Yunus Confluence Journal of Environmental Studies. 13(1), 107-118.

[31] Ulakpa, R.O.E., Iyi E.A., Okwu, V.U.D., et al., 2016. Impact of Telecommunication Masts on Environmental Planning in Enugu Urban Area of Enugu State. International Journal of Science and Healthcare Research. 1(1), 1-17.

[32] Olusegun, A., Folakemi, O., Omotayo, S., et al.,
2011. Assessment of Safety Practices in Filling Stations in Ile-Ife, South Western Nigeria. Journal of Community Medicine and Primary Health Care. 23, 9-15. https:// www.researchgate.net/publication/271501044_Assessment_of_Safety_Practices_in_Filling_Stations_in_ IleIfe_South_Western_Nigeria.

[33] Ayodele, S.J., 2011. Spatial distribution of petroleum filling station in Kaduna North. Retrieved from www. srib.com/samuelayodele1.

[34] Ehinomen, C., Adeleke, A., 2012. An Assessment of the Distribution of Petroleum Products in Nigeria. E3 Journal of Business Management and Economics. 3(6), 232-241.

[35] Mshelia, A.M., John, A., Emmanuel, D.D., 2015. Environmental Effects of Petrol Stations at Close Proximities to Residential Buildings in Maiduguri and Jere, Borno State, Nigeria. Journal of Humanities and Social Science. 20(4), 1-8.

[36] Samuel, B.A., Ogoro, M., Amanoritsewo, O.J., 2015. Petrol Filling Stations' Location and Minimum Environmental Safety Requirement in ObioAkporLGA, Nigeria. International Journal of Scientific Research and Innovative Technology. 2(11).

[37] Karakitsios, S.P., Delis, V.K., Kassomenos, P.A., et al., 2007. Contribution to ambient benzene concentrations in the vicinity of petrol stations: estimation of the associated health risk. Atmospheric Environment. 41, 1889e1902.

[38] Afolabi, O.T., Olajide, F.O., Omotayo, S.K., 2011. Assessment of Safety Practices in Filling Stations in Ile-Ife, South-Western Nigeria. Journal of Community Medicine and Primary Health Care. 23(1\&2).

[39] Ogundahunsi, D.S., 2019. Locational Analysis of Fuel Stations, in Ilesa, Osun State, Nigeria. International Journal of Development Strategies in Humanities, Management and Social Sciences. 4(2), 1-15.

[40] Boison, D.K., Asamoah, H.Y., Addison, L., et al., 2018. Assessing Factors Influencing Sales Performance and Siting of a Fuel Station Projects: Study of Spintex Road, Accra Ghana. International Journal of Social Science and Humanities Research. 6(4), 12681279.

[41] Joan, A., Ismail, W., 2020. Urban Spatial Risk Assessment of Fire from Fueling Stations on Buildings Case Study: Lubaga Division, Kampala City, Uganda. Journal of Building Construction and Planning Research. 8, 57-72.

[42] Ulasi, J.O., Uwadiegwu, B.O., Okoye, C.O., 2020. Assessment of the Level of Compliance of Petroleum Filling Stations to Development Control Standards on Land Space/Size and Setbacks in Anambra State. 
International Institute for Science, Technology and Education (IISTE): E-Journals. 12(2), 2224-5790.

[43] WHO: Why Urban Health Matters Geneva 11. Department of Petroleum Resources (DPR) Abuja Switzerland, April 2010. ttp://www. Who.Int/world (Headquarters) Nigeria.health day/2010/media/ whd2010/background.Pdf 12. Dispensing petrol as fuel: Health and safety (Accessed March 20th, 2014).

[44] Tatrai, E., Ungavry, G., Cseh, I.R., et al., 1981. The effect of long-term whole body exposure to orthoxylene on liver. In: Industrial and Environmental Xenobiotics. I. Girkt and G. L. Plaa (eds), Springer-Verlag, Berlin. pp. 161- 168.

[45] Zahlsen, K., Nielson, A.M., Eide, I., et al., 1993. Inhalation kinetics of $\mathrm{C} 8 \mathrm{-C} 10, \mathrm{I}$ - alkenes and isoalkanes in rats after repeated exposure. Pharmacol. Toxicology. (73), 163-168.

[46] Onwurah, I.N.E., 1999. Lipid peroxidation and protein oxidation in Azotobactervinelandii exposed to mercury, silver, crude oil and fenton reagent. Journal of toxic substances. 18(4), 167-176.

[47] Khan, A.A., Coppock, R.W., Schuler, M.M., et al., 2002. Biochemical changes as early stage systemic biomarkers of petroleum hydrocarbon exposure in human. Toxicolology Letters. 134(1-3), 195-200.

[48] World Health Organization (WHO), 2012.

[49] Nwanjo, H.U., Ojiako, O.A., 2007. Investigating the Potential Health Hazards of the Petrol Station Attendants in Owerri Nigeria. Journal of Applied Science and Environmental Management. 11(2), 1-5.

[50] Oladele, E.A., Michael, A.O., 2021. Health Implication on Residents Close to Petrol Station in Ife Central, Nigeria. Urban and Regional Planning. 6(2), 7986.

DOI: https://doi.org/10.11648/j.urp.20210602.13.

[51] Alam, R., Zafar, A., Ghafoor, A., et al., 2014. Lung function abnormalities among fuel filling workers in Karachi, Pakistan. Pinnacle Environmental and Earth Sciences. 1(1), 183-187.

[52] Wallace, L., 1987. The Total Exposure Assessment Methodology (TEAM) Study: Summary and Analysis, Volume I, Office of Research and Development, U.S. Environmental Protection Agency, Washington, D.C.

[53] CONCAWE, 1994. Review of europeanoil industry benzene exposure data (1986 -1992) Brussels, Belgium: Oil Companies European Organisation for Environment. Health and Safety.

[54] Duarte-Davidson, R., Courage, C., Rushton, L., et al., 2001. Benzene in the environment: an assessment of the potential risk to the health of the population.
Occup.Env. Med. 58(1), 2-13.

[55] Esteves, F.A., Pastor, A., Guaria, M., 2007. Assessing air quality inside vehicles and at filling stations by minitoring benzene, toluene, ethylbenzene and xylenes with the use of semipermeable devices.AnalyticaChimicaActa. 593(1), 108-116.

[56] Majumdar, D., Dutta, C., Mukherjee, A.K., et al., 2008. Source apportionment of VOCs at the petrol pumps in Kolkata, India; exposure of workers and assessment of associated health risk, Transp. Res. Part D. (13), 524-530.

[57] Karakitsios, S.P., Papaloukas, C.L., Kassomenos, P.A., et al., 2007a. Assessment and prediction of exposure to benzene of filling station employees. Atm. Env. 41(40), 9555-9569.

[58] Karakitsios, S.P., Delisa, V.K., Kassomenos P.A., et al., 2007. Contribution to ambient benzene concentrations in the vicinity of petrol stations: Estimation of the associated health risk. Atm. Env. 41(9), 18891902.

[59] Terrés, I.M.M., Miñarro, M.D., Ferradas, E.G., et al., 2010. Assessing the impact of petrol stations on their immediate surroundings. Journal of Environmental Management. 91(12), 2754-2762.

[60] Fracasso, M.E., Doria, D., Bartolucci, G.B., et al., 2010. Low air levels of benzene: Correlation between biomarkers of exposure and genotoxic effects. Toxicol.Lett. 192(1), 22-28.

[61] Odipe, O., Lawal, A., Adio, Z., et al., 2018. GISBased Location Analyses of Retail Petrol Stations in Ilorin, Kwara State, Nigeria. International Journal of Scientific and EngineeringResearch. (9), 790-794. https://www.researchgate.net/publication/330242228_GISBased_Location_Analyses_ of_Retail_Petrol_Stations_in_Ilorin_Kwara_State Nigeria.

[62] Olanrewaju, S., Wakeel, A., A, O., 2020. Spatial Distribution and Perceived Environmental Health Impacts of Petrol Filling Stations in Ede, Osun State, Nigeria Kaduna State. University Environmental Science Journal (KESJ). 1(1), 1-17.

[63] Aguib, A., Garni, D.A., Smith, S., 2013. Application of Remote Sensing and GIS for Locating Suitable Mangrove Plantation Sites alongthe Saudi Arabian Red Sea Coast. Available online: http://sfrc.ufl.edu/ faculty/ssmith/Sea_Coast.pdf (Accessed on 21 January 2013).

[64] Ali, Z., Khan, D., Hussain, R., 2012. Adaptation Measures in EIA and Risks Management: An Overview of the Legal Framework in Pakistan. Online J. Sci. Technol. (2), 1-11. 
[65] Appiah, D.O., Schröder, D., Forkuo, E.K., et al., 2015. Application of Geo-Information Techniques in Land Use and Land Cover Change Analysis in a Peri-Urban District of Ghana. ISPRS Int. J. Geo-Inf. (4), 1265-1289.

[66] Carrión, J.A., Estrella, A.E., Dols, F.A., et al., 2008. Environmental Decision-Support Systems for Evaluating the Carrying Capacity of Land Areas: Optimal Site Selection for Grid-Connected Photovoltaic Power Plants. Renew.Sustain. Energy Rev. (12), 23582380.

[67] Arumaningrum, D.G., 2021. Environmental Impact Assessment Study Report for The Proposed Maseki Filling Station in Kitui on Plot, L.R. Lincolin Arsyad 2014, 3. Available online: http://journal.stainkudus. ac.id/index.php/equilibrium/article/view/1268/1127(Accessed on 1 June 2021).

[68] Matori, A.N., Aulia, B.U., 2010. Suitability Analysis of Petrol Filling Station Site Using GIS. Malaysia. Constr. Res. Journal (MCRJ). (70), 1-14.

[69] Choudhury, E., Das, E., 2012. GIS and Remote Sensing for Landfill Site Selection-A Case Study on Dharmanagar Nagar Panchayet. IOSR J. Environ. Sci. Toxicol. Food Technol. (1), 36-43.

[70] Darko, S., 2015. Ghana Petrol Station Inferno Kills about 150 in Accra-BBC News. Available online: https://www.bbc.com/news/world-africa-33003673 (Accessed on 1 June 2015).

[71] Moghaddam, D.D., Haghizadeh, A., Tahmasebipour, N., et al., 2020. Introducing the Coupled Stepwise Areal ConstrainingandMahalanobis Distance: A Promising MCDM-Based Probabilistic Model for Landfill Site Selection. Environ. Sci. Pollut. Res. (27), 24954-24966.

[72] De Siqueira, C.B.A.; de Mello, R.A., 2006. Decision Support Method for Environmental Impact Assessment Using a Fuzzy LogicApproach. Ecol. Econ. (58), 170-181.

[73] Deeb, R.A., Hu, H.Y., Hanson, J.R., et al., 2001. Substrate Interactions in BTEX and MTBE Mixtures by an MTBE-Degrading Isolate. Environ. Sci. Technol. (35), 312-317.

[74] Ekanayake, L.L., Ofori, G., 2015. Construction material waste source evaluation. In Proceedings of the Second Southern AfricanConference on Sustainable Development in the Built Environment, Pretoria, South Africa. 9-11, 23-25.

[75] International Finance Corporation (IFC), 2007. Environmental, Health, and Safety Guidelines for Cement and Lime Manufacturing; IFC:Washington, DC, USA.
[76] Ghayoumian, J., Saravi, M.M., Feiznia, S., et al., 2007. Application of GIS Techniques to Determine Areas Most Suitable for Artificial Groundwater Recharge in a Coastal Aquifer in Southern Iran. J. Asian Earth Sci. (30), 364-374.

[77] Hassanain, M.A., Al-Mudhei, A., 2006. Fire Safety Evaluation of Motor Fuel Dispensing Facilities. Struct.Surv. (24), 65-76.

[78] Kirby, R.S., 2003. GIS and Public Health. Ann. Assoc. Am. Geogr. (93), 261-263.

[79] Malczewski, J., 2007. GIS-Based Multicriteria Decision Analysis a Survey of the Literature. Int. J. Geogr. Inf. Sci. (20), 703-726.

[80] Hangula, L.M., Shagama, F.N., 2020. Environmental Impact Assessment for the Establishment and Operation of a Proposed Fuel Service StationProject at Omutshona Filling Station, Okatana, Oshana Region; Omutshona Filling Station: Okatana, Namibia.

[81] Pedersen, K., Przychodzka, M., Civiš, M., et al., 2003. Environmental Impact Assessment of Petrol Usage. In Environmental Studies. Aarhus University: Aarhus, Denmark.

[82] Mohammed, M.U., Jeb, D.N., Musa, I.J., 2014. GISBased Analysis of the Location of Filling Stations in Metropolitan Kano against the Physical Planning Standards. Am. J. Eng. Res. (3), 147-158.

[83] Mulroy, P., 2012. Environmental Site Investigation and Due Diligence in current Market. In Proceedings of the Environmental APEA Petroleum Seminar, Cork, Ireland.

[84] Mundjulu, I., 2020. Environmental Scoping Report (ESR) for a Fuel Storage Facility. Ocean Bunker Petroleum Services: Windhoek, Namibia.

[85] Mwania, L.M., Kitengela, K., 2013. Proposed Construction of a Filling Station on Plot No.Makindu/ Kiboko B/687 Makindu. In Environmental Impact Assessment Study Report; Makueni County: Wote, Kenya.

[86] Njoku, C.G., Alagbe, A.O., 2015. Site Suitability Assessment of Petrol Filling Stations (PFSs) in Oyo Town, Oyo State, Nigeria. A Geographic Information Systems (GIS) Approach. IOSR J. Environ. Sci. Toxicology, Food Technol. (9), 8-19.

[87] O'Faircheallaigh, C., 2010. Public Participation and Environmental Impact Assessment: Purposes, Implications, and Lessons for Public Policy Making. Environ. Impact Assess. Rev. (30), 19-27.

[88] Ahmed, S., AbdulRahman, A.S., Kovo, A.S., et al., 2014. Health, Risk and Safety of Petrol Stations in Minna Town. An over View World Applied Sciences Journal. 32(4), 655-660. 
DOI: https://doi.org/10.5829/idosi.wasj.2014.32. 04.881 .

[89] Gonzalez-Flesca, N., Vardoulakis, S., Cicolella, A., 2002. BTX concentrations near a stage II implemented petrol station. Environmental Science and Pollution Research 9, 169e174.INSHT. 2003
National Institute of Safety and Hygiene at Work. Ministry of Labor and Immigration, Government of Spain..http://www.insht.es/portal/siteInsht/menuitem. a 82abc159115c8090128ca10060961 ca/?vgnextoid $1 / 44458908$ b5 $1593110 \mathrm{VgnVCM} 100000 \mathrm{dc}$ 0ca8c0RCRD. 